\title{
Asymmetric PCR-SSCP: a Useful Tool for Detection of OLA-DRB1 (MHC Class II) Gene Polymorphism in Slovak Improved Valachian Sheep
}

\author{
L. TKÁČIKOVÁ ${ }^{1}$, M. R. BHIDE ${ }^{1}$, I. MIKULA $^{1,2}$ \\ ${ }^{1}$ Laboratory of Biomedical Microbiology and Immunology, University of Veterinary Medicine, \\ Košice, Slovakia; ${ }^{1,2}$ Institute of Neuroimmunology, Slovak Academy of Sciences, Bratislava, Slovakia \\ Received November 22, 2004 \\ Accepted June 6, 2005
}

\begin{abstract}
Tkáčiková L., M. R., Bhide I. Mikula: Asymmetric PCR-SSCP: a Useful Tool for Detection of OLA-DRB1(MHC class II) Gene Polymorphism in Slovak Improved Valachian Sheep. Acta Vet. Brno 2005, 74: 275-278.

Detection of OLA-DBR1 (exon 2) gene polymorphism is presented in the paper. Rapid and inexpensive polymorphism detection method, namely, single stranded conformation polymorphism (SSCP) was assessed. Modification of the SSCP to asymmetric PCR-SSCP enabled a more simplified assay for the clustering the individuals into distinct groups (profiles) on the basis of band patterns, as only single stranded amplicons were detected. A total of 400 Valachian sheep were included in the study. In this cohort, 25 distinct clusters were noticed. Among 25 groups the frequency of $k$ profile was the highest (28\%), followed by profile $e(21 \%), p(16 \%), w(9 \%)$ and $d$ (9\%). The homologous SSCP as well as asymmetric-PCR-SSCP patterns were observed among the twins: This finding has shown the sensitivity of both methods to segregate the individuals on the basis of their allelic forms.
\end{abstract}

MHC, OLA-DRB1 gene, SSCP, polymorphism, sheep

The major histocompatibility complex (MHC) plays a central role in the immune response of vertebrates. The extreme polymorphism in MHC genes enables the host to recognize enormous numbers of foreign peptides to trigger an immune reaction. The class II gene region of the sheep MHC (OLA) has an organization similar to that of humans (S c ott et al. 1987). Within this region, two sub-regions, namely, DR and DQ exhibit higher polymorphism (A mills et al. 1998). Among OLA class II genes, the DRB1 locus is highly polymorphic. In particular the polymorphism is present in exon 2 , which encodes the antigen-binding site. To date nearly 160 OLA-DRB1 alleles have been recorded from various sheep breeds (Konnai et al. 2003).

In the population genetics, analysis of large number of samples is a prerequisite. Though the DNA sequencing is gold standard for most of the phylogenetic studies, the cost requisite for such analysis is quite high as well as it is time consuming. Recently, simple and rapid techniques like PCR-RFLP (restriction fragment length polymorphism) and DGGE (denaturing gradient gel electrophoresis) have been used by different researchers for the detection of MHC gene polymorphism (Aldridge et al. 1998; Konnai et al. 2003). These techniques enable to group the individuals into clusters on the basis of gene polymorphism. However, the amount and cost of restriction enzymes required for analyzing large numbers of samples may jeopardize the use of RFLP.

SSCP (single stranded conformation polymorphism) offers a simple and inexpensive method for genotyping. Hitherto, SSCP has been extensively used in biomedical research, especially for rapid bacterial genotyping. In this study we used simple SSCP as well as modified asymmetric PCR-SSCP for DRB1 genotyping in autochthonous Valachian sheep breed. To our knowledge, no report is as yet available elaborating the OLA-DBR1 alleles present in the Valachian breed. Considering the recent interest in Valachian sheep breeding

Address for correspondence:

Doc. MVDr. I. Tkáčiková, PhD.

Laboratory of Biomedical Microbiology and Immunology

University of Veterinary Medicine

Komenského 73,041 81 Košice, Slovakia
Phone: +421556336614

Fax: +421556323666

E-mail: tkacikov@uvm.sk

http://www.vfu.cz/acta-vet/actavet.htm 
in Middle and Eastern European countries it is necessary to know the natural disease resistance ability of this sheep breed. The results presented in this study create a benchmark for further gene polymorphism study influencing the ability of disease resistance or susceptibility of this breed.

\section{Materials and Methods}

Animals

A total of 400 autochthonous Valachian sheep (including 20 twins) were included in the study from different farms located in Eastern Slovakia. Genomic DNA was isolated from blood leukocytes and DNA was stored at $-20^{\circ} \mathrm{C}$ until used.

\section{PCR amplification}

Two PCR primers forward (5'-TCT CTG CAG CAC ATT TCC TGG-3') and reverse (5'-CTC GCC GCT GCA CAG TGA AAC-3') (Ammer et al. 1992) were used to amplify entire exon 2, with flanking intron. The total product length was $279 \mathrm{bp}$. Reactions were performed by using $0.6-1.3 \mu \mathrm{g}$ of genomic DNA in a $50 \mu \mathrm{l}$ final volume. The PCR reaction mixture contained $100 \mu \mathrm{M}$ of each dNTP, $0.5 \mu \mathrm{M}$ of each primer, $1.5 \mathrm{mM} \mathrm{MgCl}_{2}$, and $1 \mathrm{U}$ of Taq polymerase. The conditions for PCR amplification were as follows: 94 oC for $5 \mathrm{~min}$, followed by 35 cycles of $94^{\circ} \mathrm{C}$ for $90 \mathrm{~s}, 60^{\circ} \mathrm{C}$ for $30 \mathrm{~s}$ and $72{ }^{\circ} \mathrm{C}$ for $90 \mathrm{~s}$ with final extension at $72{ }^{\circ} \mathrm{C}$ for $10 \mathrm{~min}$.

To produce single stranded amplimers, asymmetric PCR was performed. In short, the PCR reaction mixture was maintained as described previously except the concentration of DRB1R primer was reduced by 100 folds. For amplification of asymmetric amplimers the same PCR cycles were used as described above.

Single-Strand Conformational Polymorphism Analysis

Five $5 \mu 1$ of each amplified product was mixed with $3 \mu$ l of loading dye ( $98 \%$ formamide, $10 \mathrm{mM} \mathrm{EDTA}, 0.025 \%$ bromophenol blue, $0.025 \%$ xylene-cyanol). Double stranded amplimers were subjected to denaturation at $95{ }^{\circ} \mathrm{C}$ for $8 \mathrm{~min}$ and samples were rapidly cooled on ice. Denaturated as well as single stranded amplimers derived form asymmetric PCR were loaded on acrylamide isacrylamide (37.5:1; Bio-Rad) gels. In the study we tried 6, 8, 10 and $14 \%$ polyacrylamide gels. The concentration of glycerol in gel was kept either $5 \%$ or $10 \%$ to compare the effect on resolution. Electrophoresis was performed using $200 \mathrm{~V}$ at $5{ }^{\circ} \mathrm{C}$ in $0.5 \times \mathrm{TBE}$ buffer. Gels were silver-stained according to the method of Bassam et al. (1991). Different electrophoresis runs (14, 16, 18 and 20 hours) were also tried in the study.

\section{Results}

Genotyping of OLA-DRB1-exon 2 revealed a total of 25 groups on the basis of PCRSSCP. Genogroups obtained by the SSCP of double stranded amplimer were correlated with the results of SSCP performed by using the products of asymmetric PCR (amplified single stranded amplimers). However, the results obtained from asymmetric PCR-SSCP were much easier for further analysis and clustering of the profiles. Fig. 1 and Fig. 2 (Plate XIV) present the PCR-SSCP and asymmetric PCR-SSCP profiles representative for each cluster.

Among different concentrations of polyacrylamide used in the study $14 \%$ gel yielded the most satisfactory results. In case of lower percentages diffused bands were observed (data not presented). The use of $10 \%$ glycerol improved the band resolution of the polyacrylamide gel. Similarly, 20 hours of electrophoresis run separated the band more distinctly.

Among 25 clusters the frequency of $k$ profile was the highest $(28 \%)$ followed by groups $e$ $(21 \%), p(16 \%), w(9 \%)$ and $d(9 \%)$ (Fig. 3). SSCP patterns for the twins were identical except in 3 twin pairs.

\section{Discussion}

The Valachian sheep is the westernmost of Zackel sheep breeds, which came from the Romanian Southern Carpathians to the High Tatra and the Low Tatra mountains in Slovakia. The Improved Valachian breed is the well-represented sheep breed in Slovakia along with other breeds like Tsigai and Merino. Valachian sheep are mainly used for milk production. During the last five years the interest in sheep breeding has revived in Slovakia, with emphasis on the improved Valachian breed. 

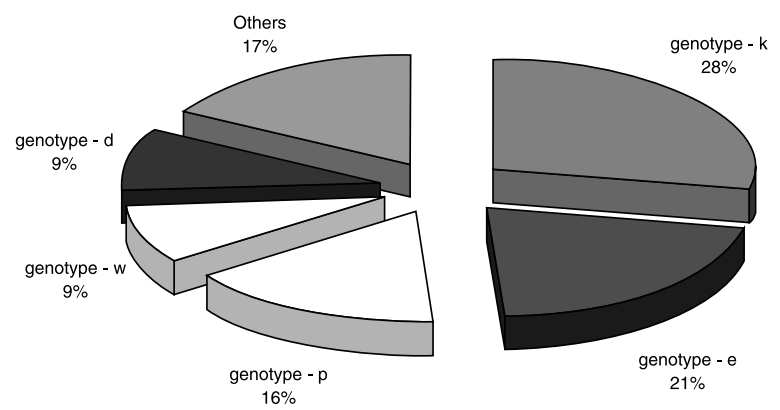

Fig. 3. Frequencies of MHC-DRB1 allelic profiles in Slovak Valachian sheep breed. Others (17\%) were constituted by 20 different profiles reveled from PCR-SSCP analysis.

Table 1. SSCP profiles showing either homozygosity or heterogygosity in the Valachian sheep population

\begin{tabular}{|l|l|l|}
\hline Zygosity & SSCP profile & Total Percentage \\
\hline Homozygotes & b, f, i, j 1, s & $24 \%$ \\
\hline Heterozygotes & a, c, d, e, g, h, k, m, n, o, p, q, r, t, u, v, w, x, y & $76 \%$ \\
\hline
\end{tabular}

Homo- and heterozygosity was confirmed on the basis of asymmetric PCR- SSCP.

MHC gene region is the most important because of its relationship with disease resistance or susceptibility. Several studies (Schwaiger et al. 1995; Buitkamp et al. 1996; Charon et al. 2002) have shown the association of OLA-DRB1 alleles with reduced faecal egg counts in parasitic infestations. Antibody production was also influenced by MHC microsatellite alleles in the nematode infestation (Outteridge et al. 1996). DRB1-exon 2 is particularly associated with parasitic infestations. Nonetheless, ovine MHC class II DRB1 alleles were also reported to be associated with resistance or susceptibility to development of bovine leukemia virus-induced ovine lymphoma (Naga oka et al. 1999).

The extreme polymorphism in DR region was confirmed in our experiment recording 25 different SSCP patterns. Heterozygosity was significantly higher $(96 \% ; P<0.05, t$-test $)$ among the Valachian sheep as described in Table1. Different SSCP patterns of DRB1 gene have been reported earlier (Kostia et al. 1998; Jugo and Vicario 2000; Jugo and Vicario 2001). The frequency of the $k$ genogroup was the highest (28\%) followed by genogroup $e(21 \%)$. The sequencing of alleles from each SSCP group can help to determine the possible natural disease resistance of Valachian sheep. Also the asymmetric PCR-SSCP coupled with allele sequencing can prove as a prominent molecular marker system. From 20 twins pairs 17 pairs had similar SSCP patterns confirming the sensitivity of segregation ability of SSCP.

Because of the multiple polymorphism and heterogeneity, the results obtained in DGGE, RFLP as well as SSCP analysis are difficult to analyze and distinguish them in to the clusters. The use of asymmetrical PCR-SSCP proved to be the challenging modification to ease the data processing and cluster analysis. Moreover two distinct bands (in case of heterozygotes) and single band (in case of homozygote) appeared in asymmetrical PCR-SSCP can be dissected, purified and sequenced for pin-point sequenced based identification of alleles. Kostia et al. (1998) also reported the simplicity and speedy nature of SSCP method to accelerate DRB1 genotyping of sheep breeds. 
In short, the application of asymmetric PCR-SSCP technique can facilitates the good molecular marker system for gene polymorphism detection in a large number of individuals, which is usually difficult by using traditional typing techniques.

\section{Asymetrická PCR-SSCP ako užitočný nástroj na detekciu polymorfizmu v OLA-DRB1(MHC trieda II) géne slovenských oviec plemena Zošlachtená valaška}

V práci je prezentovaná detekcia polymorfizmu v 2 exóne OLA-DBR1 génu. Bola použitá rýchla a málo náročná metóda stanovenia jednovláknového konformačného polymorfizmu (Single Stranded Conformation Polymorphism, SSCP). Modifikácia SSCP na asymetrickú PCR-SSCP umožní ovela jednoduchšie rozdelenie jedincov do jednotlivých genetických skupín na základe rozdielnych pruhových profilov, ked’̌e sú analyzované iba jednovláknité amplikóny. Do tejto štúdie bolo zahrnutých 400 oviec plemena Zošlachtená valaška, pričom bolo zaznamenaných 25 rozdielnych genetických skupín. Najčastejšie boli zastúpené skupiny $k(28 \%), e(21 \%), p(16 \%), w(9 \%)$ a $d(9 \%)$. U dvojičiek bol pozorovaný výskyt homológnych vzorov tak v SSCP ako aj v asymetrickej PCR-SSCP, čo poukazuje na senzitivitu daných metód pri segregácii jednotlivých zvierat na základe prítomnosti jednotlivých alel.

\section{Acknowledgements}

This research was supported by Slovak Grant Agency VEGA 1/0433/03.

\section{References}

AMMER H, SCHWAIGER FW, KAMMERBAUER C, GOMOLKA M, ARRIENS A, LAZARY S, EPPLEN JT 1992: Exonic polymorphism vs. intronic simple repeat hypervariability in MHC-DRB genes. Immunogenetics 35: $332-340$

ALDRIDGE BM, MCGUIRK SM, CLARK RJ, KNAPP LA, WATKINS DI, LUNN DP 1998: Denaturing gradient gel electrophoresis: a rapid method for differentiating BoLA-DRB3 alleles. Anim Genet 29: 389-394

AMILLS M, RAMIYA V, NORIMINE J, LEWIN HA 1998: The major histocompatibility complex of ruminants. Rev Sci Tech 17: 108-120

BASSAM BJ, CAETANO-ANOLLES,G, GRESSHOFF PM 1991: Fast and sensitive silver staining of DNA in polyacrylamide gels. Anal Biochem 196: 80-83

BUITKAMP J, FILMETHER P, STEAR MJ, EPPLEN JT 1996: Class I and class II major histocompatibility complex alleles are associated with faecal egg counts following natural, predominantly Ostertagia circumcincta infection. Parasitol Res 82: 693-696

CHARON KM, MOSKWA B, RUTKOWSKI R, GRUSZCZYNSKA J, ŚWIDEREK W 2002: Microsatellite polymorphism in DRB1 gene (MHC class II) and its relation to nematode faecal egg count in Polish Heath sheep. J Anim Feed Sci 11: 47-58

JUGO BM, VICARIO A 2000: Single-strand conformational polymorphism and sequence polymorphism of MhcDRB in Latxa and Karrantzar sheep: implications for Caprinae phylogeny. Immunogenetics 51: 887-897

JUGO BM, VICARIO A 2001: Lymphocyte antigens in sheep: linkage to the MHC class II DRB1 gene. Eur J Immunogenet 28: 451-458

KONNAI S, NAGAOKA Y, TAKESIMA S, ONUMA M, AIDA Y 2003: Technical note: DNA typing for ovine MHC DRB1 using polymerase chain reaction-restriction fragment length polymorphism (PCR-RFLP). J Dairy Sci 86: $3362-3265$

KOSTIA S, KANTANEN J, KOLKKALA M, VARVIO SL 1998: Applicability of SSCP analysis for MHC genotyping: fingerprinting of OLA-DRB1 exon 2 alleles from Finnish and Russian breeds. Anim Genet 29: 453455

NAGAOKA Y, KABEYA H, ONUMA M, KASAI N, OKADA K, AIDA Y 1999: Ovine MHC class II DRB1 alleles associated with resistance or susceptibility to development of bovine leukemia virus-induced ovine lymphoma. Cancer Res 59: 975-981

OUTTERIDGE PM, ANDERSSON L, DOUCH PG, GREEN RS, GWAKISA PS, HOHENHAUS MA, MIKKO S 1996: The PCR typing of MHC-DRB genes in the sheep using primers for an intronic microsatellite: application to nematode parasite resistance. Immunol Cell Biol 74: 330-336

SCHWAIGER FW, GOSTOMSKI D, STEAR MJ, DUNCAN JL, MCKELLAR QA, EPPLEN JT, BUITKAMP J 1995: An ovine major histocompatibility complex DRB1 allele is associated with low faecal egg counts following natural, predominantly Ostertagia circumcincta infection. Int J Parasitol 25: 815-822

SCOTT PC, CHOI CL, BRANDON MR 1987: Genetic organization of the ovine MHC class II region. Immunogenetics 25:116-122 
Tkáčiková L. et al.: Assymetric PCR-SSCP ... pp. 275-278
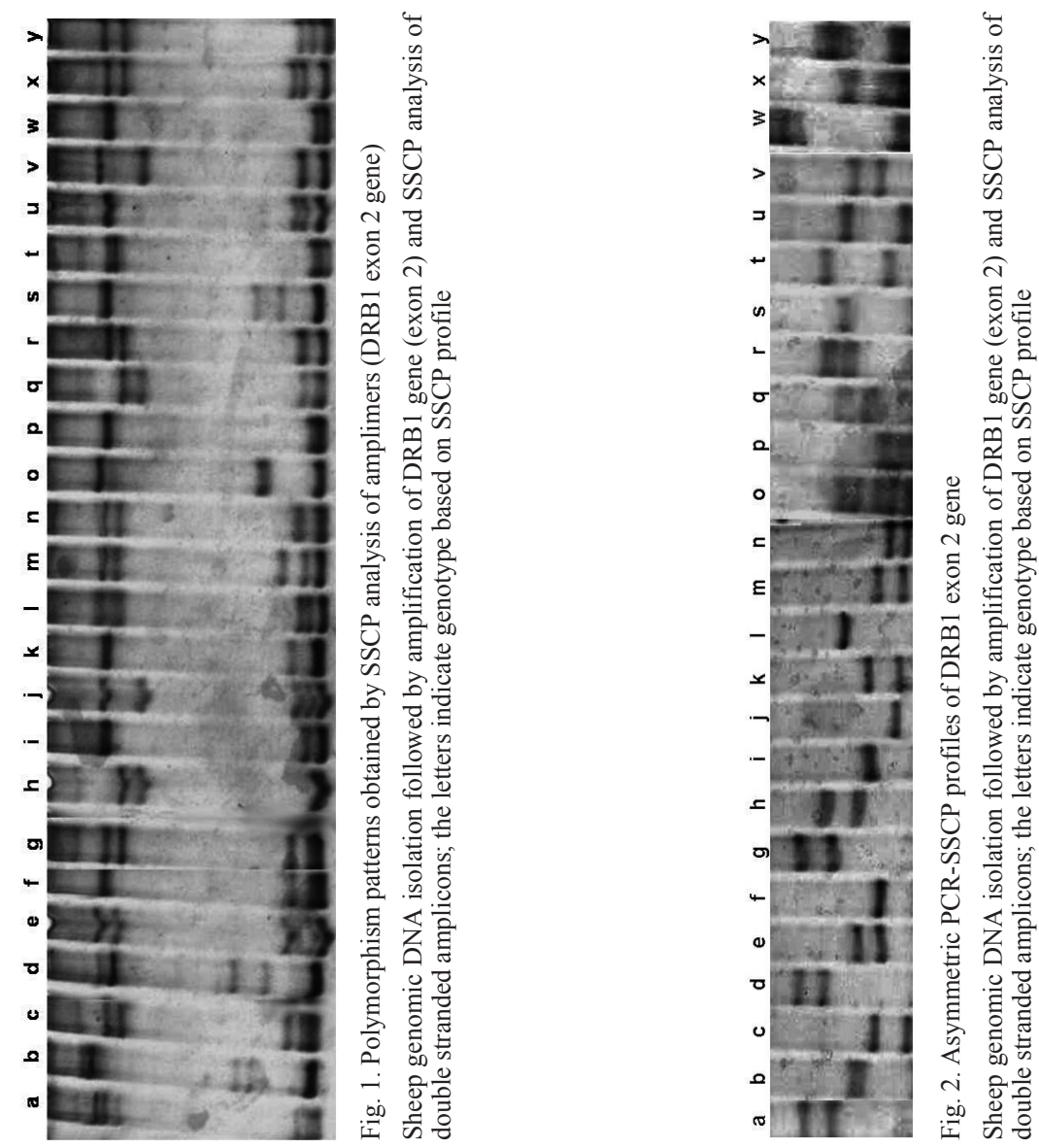